\title{
410 難加工材のスプリングバック特性に及ぼす曲げ線圧縮の効果 \\ Springback properties with compression for several materials
}

\author{
○学 井上 真吾(香川高専・専) 正 酒井 孝(成蹊大学) 正 福井 智史 (香川高専) \\ 小俣 均((株)アマダ) 小山 純一((株)アマダ) \\ Shingo INOUE, Kagawa National College of Technology \\ Takashi SAKAI, Seikei Univercity \\ Satoshi FUKUI, Kagawa National College of Technology \\ Hitoshi OMATA, AMADA CO.,LTD. \\ Jun-ichi KOYAMA, AMADA CO.,LTD.
}

\section{1. 緒言}

曲げ塑性加工を行う金属材料は，冷間あるいは熱間におい て圧延加工が施されている. したがって，納入材の段階です でに集合組織や残留応力等による材料特性の変化が起きてい る.よって, 納入材に曲げ加工を行う場合でも, RD 方向に 対する角度によっては材料特性值が異なることが予想される。 また，実際には RD 方向を統一した一枚の板であっても板の 各部分において材料特性値は異なり, 高精度曲げ加工を行う らえでは考慮の必要性がある.

そこで本研究では，そのような特性值の変化を無視できる ような方法として曲げ線の圧縮を考案，試験を行って挙動を 把握し，そして加工現場において実行することで，より高精 度の曲げ加工を実現することを最終目標とする.

\section{2. 実験および解析方法}

本報では，一般的な鉄鋼材料として SUS304，SPCC の二つ の材料を用いて，一枚の板での材料特性值分布について RD 方向角度を変えて調査した。 また，二つの材料に加えて SUS430 も含め, 実際に曲げ線圧縮での圧縮割合を変えつつ曲 げ試験を行い，各目標曲げ角度における各 $\mathrm{RD}$ 方向角度での スプリングバック量のデータを採取した.

\section{1 納入材の材料特性值分布}

Figs.1,2にSUS304材およびSPCC材における一枚の板での， (a)加工硬化指数 $n$ と(b)塑性係数 $F$ の変化をそれぞれ示す.

Figs.1,2 から分かるように, RD 方向の変化による材料特性 値の変化，さらには同じ $\mathrm{RD}$ 方向角度でも一枚の板の中での 特性值の分布は大きく, 最大 $8.1 \%$ の高位差があり, 高精度加 工を行うためには，制御する必要性が十分にあるということ がわかった。

しかしながら，その材料特性値の分布の様子は， $\mathrm{RD}$ 方向 が変化することによって板全体の值に大きな違いがあり，そ れぞれの角度での板の中での值の大きさのばらつきの様子も 異なっていることが分かる. また, $n$ 值と $F$ 值との間でも, SPCC 材では関連性がみられるが, SUS304 材では $90^{\circ}$ 以外の 場合にはほとんど関連性が見られない，さらに，SPCC材と SUS304 材との間でも関連性は見られない.

つまり， RD 方向が変化することによって值が変わること
はもちろん, $n$ 値と $F$ 值との間での関連性もはっきりせず, 材料ごとにも全く違った分布の状況となっており, 分布の因 果関係や状況を把握，さらには予測する事は非常に困難であ るということが予想される.

\subsection{SUS304 材での曲げ試験結果}

Figs.3,4 に SUS304 材における板厚 $1.2 \mathrm{~mm}$ および $1.6 \mathrm{~mm} の$ 材料での曲げ線圧縮後の試験の結果を示す，それぞれのグラ フを見ると，それぞれ SB 量が増加している様子が見て取れ る.これは，圧縮により板厚が減少していること，さらには 加工硬化により降伏応力が上昇していることによる当然の結 果であると考えられる. しかし，RD 方向によって，Fig.3 と Fig.4 ではでは圧縮割合が高くなるにつれて近似直線におい ては逆の傾向を示していることがわかる.これは，1.2mm 材 と $1.6 \mathrm{~mm}$ 材を作製する上で圧延などの回数が異なることは明 白であり，それによって傾向が変わるということが関係して いる. あるいは, $1.2 \mathrm{~mm}$ 材では一つの板からすべての圾験片 を採取したことに対して，1.6mm 材では $0^{\circ}$ と $90^{\circ}$ それぞれ の圾験片を作製する上で，違う板から試験片を採取したこと によるロット № の違いが影響しているのではないかと考え られる。

\subsection{SUS430 材, SPCC 材での曲け試験結果}

Figs. 5,6 に SUS430 及び SPCC 材板厚 $1.2 \mathrm{~mm}$ の材料での曲 げ線圧縮曲げ圾験結果を示す． Fig.5 での SUS430 材では端部 にレーザー加工を施した，熱影響を受けたと考えられる材料 において試験片を作成し，試験を行った。 そして，谷口らの 研究において現れた結果と同様に, SB 量が熱影響を受けた材 料では $1.7^{\circ}$ から $2.5^{\circ}$ 程度に上昇している様子が見られる. これは，曲げ線圧縮を施しても熱影響など，材料の組織や特 性を大きく変えうるような根本的な材料特性の変化に対して は，曲げ線任縮をすることによってその影響を無視できるよ うにするといったような影響力はないということがわかる.

次に, Fig.6の SPCC 材での試験結果に関しては，曲げ線圧 縮割合 $8 \%$ 程度において近似直線が交点を示していることが わかる.だが，この結果に関して，3.1の考察で述べたように ロットNoによっては違う結果が出ることも予想される.

そのようなことも踏まえながら,これからさらにデータを取 り,より確実な結果を出していく予定である. 


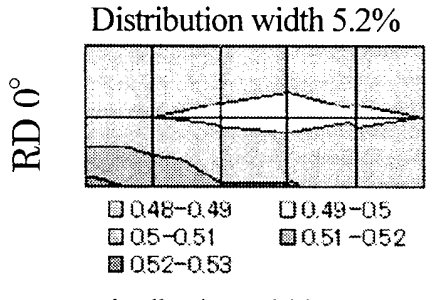

Distribution width $5.6 \%$

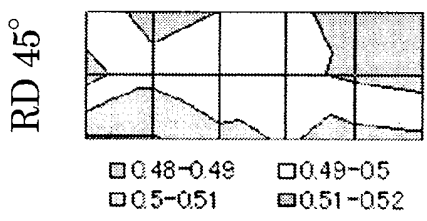

Distribution width $8.1 \%$

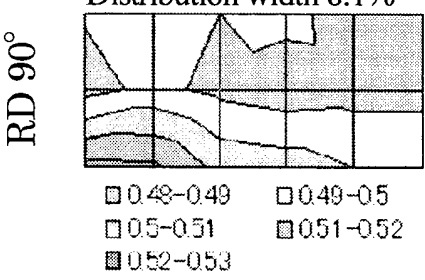

(a) Work hardening exponent distribution, $n$

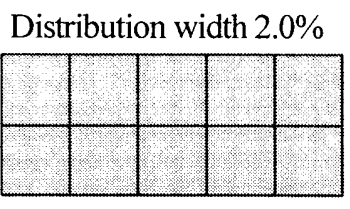

D 1590-1630

Distribution width $2.4 \%$

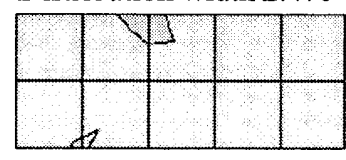

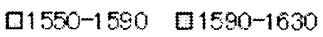

Distribution width $6.2 \%$

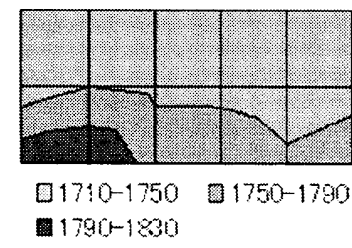

(b) Plastic exponent distribution, $F$

Fig.1 Work hardening exponent and plastic exponent distribution for SUS304.

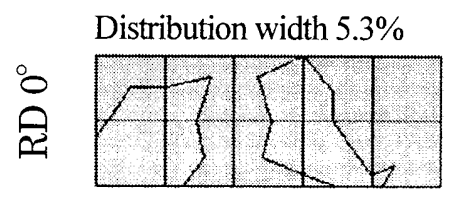

Distribution width $2.5 \%$

$\square 0.19-0.195 \square 0.195-0.2$

$\square 535-545 \quad \square 545-555$

Distribution width $6.2 \%$

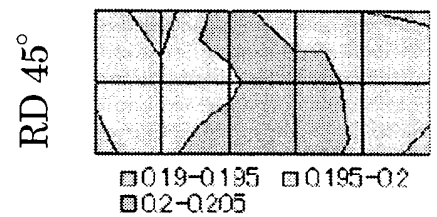

Distribution width $6.8 \%$

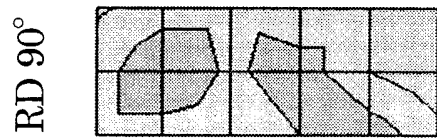

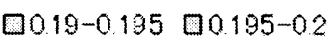

$002-0200$

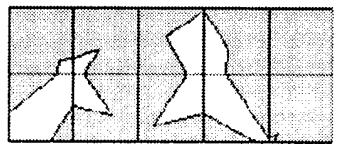

Distribution width $3.4 \%$

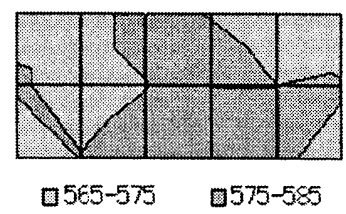

Distribution width $2.8 \%$

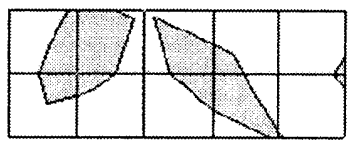

$\square 535-545 \quad \square 545-555$ $\square 555-505$

(a) Work hardening exponent distribution, $n$

(b) Plastic exponent distribution, $F$

Fig.2 Work hardening exponent and plastic exponent distribution for SPCC.

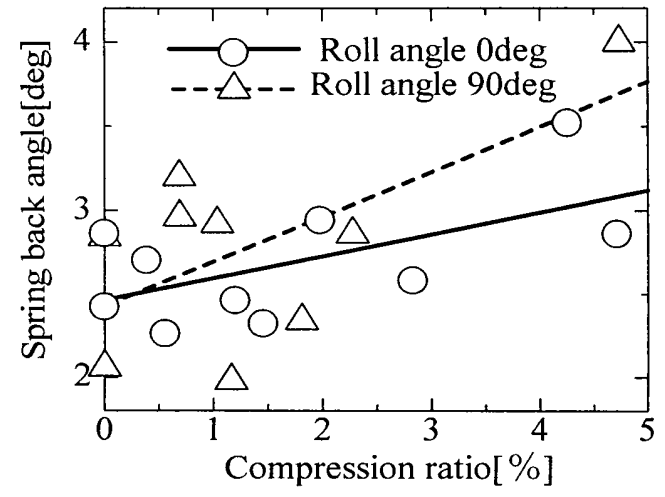

Fig.3 Springback properties for SUS304, $t=1.2 \mathrm{~mm}$ after compression

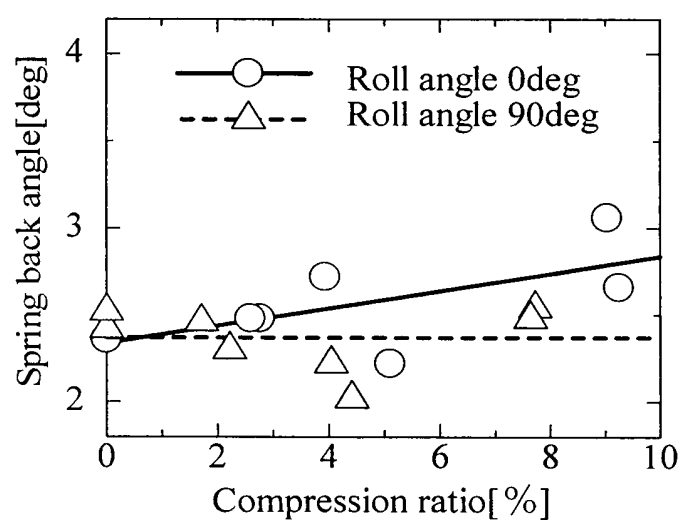

Fig.4 Springback properties for SUS304, $t=1.6 \mathrm{~mm}$ after compression

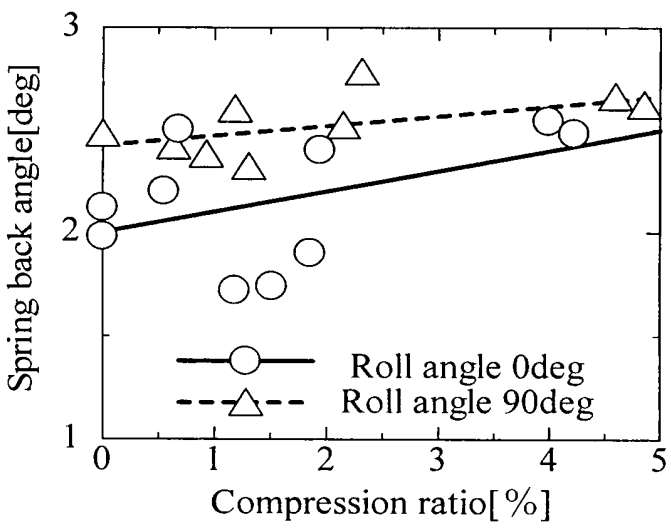

Fig.5 Springback properties for SUS430, $t=1.2 \mathrm{~mm}$

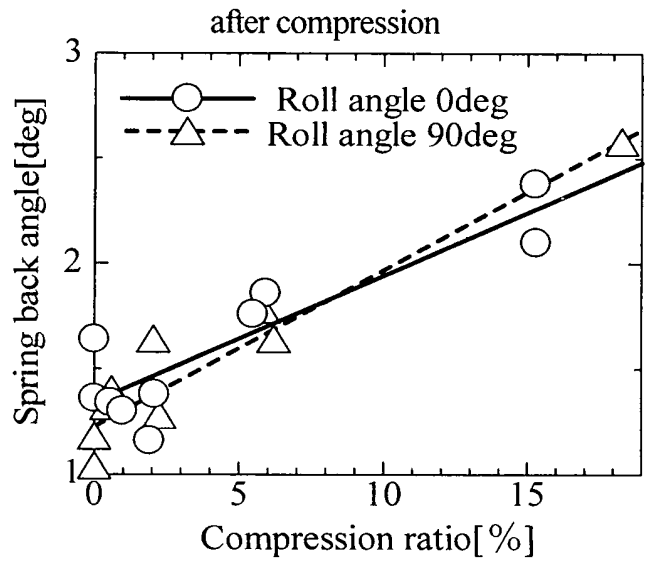

Fig.6 Springback properties for SPCC, $t=1.6 \mathrm{~mm}$ after compression 